\title{
The Use of Discretion among Government Officers in Malaysia: Driven by Moral Obligation or Nature of Work?
}

\section{Mariny Abdul Ghani, Noor Azizah Ahmad}

To Link this Article: http://dx.doi.org/10.6007/IJARBSS/v10-i11/9077

DOI:10.6007/IJARBSS/v10-i11/9077

Received: 16 September 2020, Revised: 20 October 2020, Accepted: 17 November 2020

Published Online: 26 November 2020

In-Text Citation: (Ghani \& Ahmad, 2020)

To Cite this Article: Ghani, M. A., \& Ahmad, N. A. (2020). The Use of Discretion among Government Officers in Malaysia: Driven by Moral Obligation or Nature of Work? International Journal of Academic Research in Business and Social Sciences, 10(11), 1517-1579.

Copyright: (c) 2020 The Author(s)

Published by Human Resource Management Academic Research Society (www.hrmars.com)

This article is published under the Creative Commons Attribution (CC BY 4.0) license. Anyone may reproduce, distribute, translate and create derivative works of this article (for both commercial and non-commercial purposes), subject to full attribution to the original publication and authors. The full terms of this license may be seen at: http://creativecommons.org/licences/by/4.0/legalcode

Vol. 10, No. 11, 2020, Pg. 1517 - 1579

Full Terms \& Conditions of access and use can be found at http://hrmars.com/index.php/pages/detail/publication-ethics 


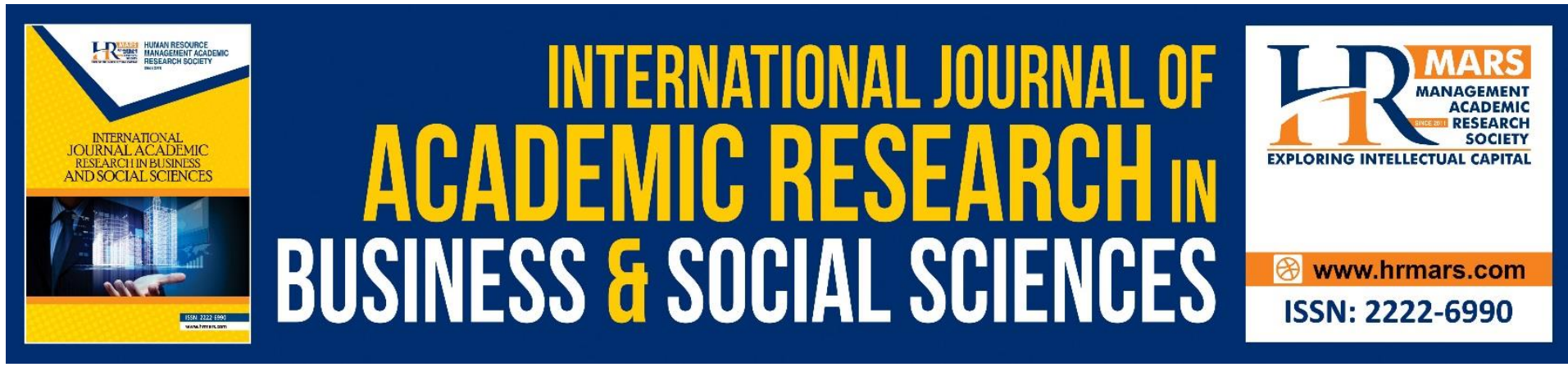

\title{
The Use of Discretion among Government Officers in Malaysia: Driven by Moral Obligation or Nature of Work?
}

\author{
Mariny Abdul Ghani, Noor Azizah Ahmad \\ School of Applied Psychology, Social Work and Policy, Universiti Utara Malaysia, Kedah, \\ Malaysia \\ Email: mariny@uum.edu.my
}

\begin{abstract}
This paper attempts to address the issues and challenges faced by the street level bureaucrats when it comes to discretionary decisions in the performance of their duties. The exercise of discretion in delivering government services requires greater control over their working practices. The participants involved in the study were 80 civil servants from different states in the Northern Region of Malaysia. Data collection methods employed include focus group discussion as well as information gathered from self-completed questionnaires of the participants. The results showed that majority of the officers had used discretion in some point of their routine tasks. The determinants, however, entail various underlying reasons which driven by diverse perspectives.
\end{abstract}

Keywords: Discretion, Street Level Bureaucrats, Civil Servants, Service Delivery, Malaysia.

\section{Introduction}

A service delivery framework describes on a set of principles, standards, policies and guidelines on how the service provider operates its system in offering persistent and a clear-cut procedure to the service users. In this particular study, the general public benefits from the services offered by the governmental organizations and agencies whom being referred to as the providers. Public service workers who interact directly with citizens in the course of their respective jobs and who have substantial discretion in the execution of their work are labelled as street level bureaucrat (Lipsky, 1980). These government workers also serve not only as the implementation agents (Hupe and Hill, 2007), yet they produce the public policy (Meyers and Vorsanger, 2003).

The concept of street level bureaucrats becomes an essence in understanding the nature of this group of people. They are perceived as the frontline professional whom practice in public organizations. Reference Lipsky, (1980) concurs with the claim that frontline workers which their job description largely involves serving the community will prone to using discretion when handling the tasks. This is because the sense of emotions inevitably incorporated in their work as they experience human interactions, gestures and 
thinking. Thus, these elemens to a certain extent may indirectly cause to influence their decision making process.

Another claims which challenged the neutrality of the civil servants when serving the public are, how well these human relations experiences can be dissected from the aim of achieving the purpose of the policy implemented (Meyers and Vorsanger, 2003). It is almost impossible to work effectively step-by-step in delivering services without compromising on the standard of the procedure due to limitation of time, information, manpower or any other resources which make the discretion is irresistable.

\section{Literature Review}

Frontline workers hold responsibility in their job to deal with numerous issues raised by the clients on daily basis. It means a direct contract within civil servants' job scope whom responsible in managing public service organization and conduct policy or economic analyses to the society. Thus, discretion has become part and parcel in the routine tasks when dealing with various types of client. In contrary, these government officers must conform to what that has been determined by authority although the possibility for conflict of role is obvious. As a civil agent working for the people, they occasionally might have to use discretion in order to facilitate the service delivery in regard to policy implementation. The definition of discretion can be explained in various dimensions. Discretion as 'a hole in the doughnut', an area left open by a surrounding belt of restriction (Dworkin, 1977). From this point of view, there is likelihood of discretion to exist even though under a certain contraint. Discretion may interfere the task at hand and give impact to policy implementation. Other researchers found out that discretion is closely related to choice and autonomy. Reference Galligan (1990) considers discretion a sphere of autonomy within which one's decisions in some degree; a matter of personal judgment and assessments. It all depends to one's personal view while working with client whether to use discretion or not. It also comes down to ones moral principles which informed the discretion decision.

There are three types of discretion which been identified within street level bureaucracies perspective. First, discretion rule is bounded by legal, fiscal or organization constraints. Secondly, value discretion that may be determined by notions of fairness or justice and can involve professional and organizational codes of conduct and ethics. The third one is task discretion which the ability to carry out prescribed tasks that involve working with clients. These types of discretion show the great influence of street level bureaucrats. The workers may experience all the discretion types but in different degree level. Therefore, the power of discretion is seemingly undeniable and essential to enhance the productivity of working while attending the clients.

Discretion as a range of choice within a set of parameters that circumscribes the behaviour of the individual service provider (Scott, 1997). Further, the study stressed on behaviour of service provider which in fact lead to discretion. Reference Tummers, Steijn, and Bekkers, (2012) pointed out that discretion is the freedom in which street level bureaucrats make choices concerning the provision, quantity and quality of resources alongside the sanctions or rewards available to the public. In short, there is certain condition that lead the officers to use discretion in the decision making and judgement process.

Likewise, discretion is unmeasurable and very unique and personal to those who exercising it (Taylor, 2007). Therefore it is hard to tailored it in form of standardized tool 
because discretion itself is a very abstract in nature. Up to now, there is no classification system has been developed to list down specific types of discretion-infused policy implementation (Loyens and Maesschalck, 2010). The main objective in using discretion is to produce positive outcome for clients. In line with that, professionals ought to be motivated to help clients and in position to do so. Another criteria which support the use of good discretion includes values, dispositions, knowledge and skills, appropriate tools and administrative support. Discretion has its own impact. Researchers do not only mention the community, with its specific culture, typical problems, unique expectations; other service providers too might even affected by discretion (Sibanda, 2016; Gambrill, 2011).

\section{Method}

The study uses quantitative approach to capture the description of government officers' tendency of using discretion in their routine tasks. The participants were selected from one specific government agency in Malaysia which is vital and very significant with public setting. The agency's headquater is in Putrajaya and branched down to every states with several offices in the district level. The scope of the study covers the Northern region part which include the state of Kedah, Perlis and Pulau Pinang.

In addition to enhance the richness of the data, focus group discussion was conducted in order to elicit firsthand valueable information regarding the use of discretion in service delivery as well as challenges encountered when performing the duties. The interview guide for the discussion were designed based on related past studies in the area of interest (Marschall, Shah, and Ruhil, 2011; Mutereko, 2009; Belabas and Gerrits, 2017). The interview time for focus group discussion ranges between 35 to 50 minutes whereas the average time for the participants completing the suvey was 15 minutes. Prior to data collection stage, official permission was granted from the headquarter's office and all selected states together with its district offices were informed in writing concerning the details of the study. All participants had acknowledged about their voluntary involvement in the study by indicating their signature on the informed consent form.

Further, in the self-reporting questionnaires technique, the participants were asked to provide their demographical characteristics as well as work background including professional position in the organization and their work practices in relation to decisions on the basis of discretion. Fig. 1 shows the flow chart of the data collection stage comprising of survey using questionnaire and discussion from the focus group of the government officers. 


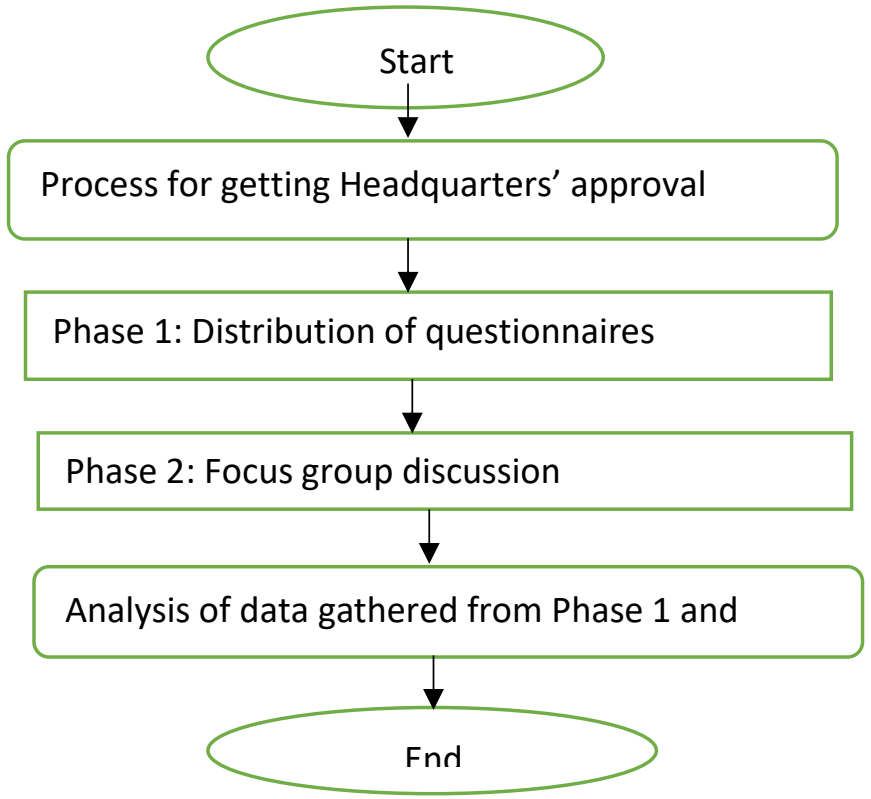

Fig. 1 Data collection process

Almost 60 per cent of the total number of the participants recorded as female and another 40 per cent was male $(n=33)$. Majority of the officers work in Kedah state $(n=44)$, followed by Pulau Pinang $(n=29)$ and Perlis with only seven officers participated. The distribution seems to be acceptable as Perlis has the smallest area geographically; size-wise compared to the other two states. Many of the officers are positioned at higher ranks in the Support Group Scheme (grade 29 and above). A total of 51 participants admitted to have more than five years of working experience in the agency. This profile alligned with the study from Sweden which suggests length of work experience affects the professional discretion decisions (Taylor, 2007). The staff mostly work at the counter service $(n=66)$, which they served as the front workers for the agency in taking cases from the general public.

\section{Results and Discussion}

The results in his study were analysed through descriptive statistics and qualitative approach from transcriptions of the staff focus group discussion. This section is divided into:

\section{Descretion Decisions in Workplace}

The element of discretion as shown in TABLE I demonstates that these street level bureaucrats were highly possible to use of discretion in their routine tasks when dealing with clients from all walks of life. As most of them are stationed at the reception counters, they are among the first person that the public will encounter when seeking government services.

In this particular agency, the services provided include receiving cases for actions in terms of investigation of the problem, advocacy works, counselling and therapy session, financial aids, outreach programs on social issues for the community, as central liaison agency to other relevant governmental as well as non-governmental organizations in servicing the citizens and many more.

Astoundingly, the main findings in this study exhibits that the government officers in this particular agency prone to apply discretion in the workplace. The discovery, however, should be treated very cautiously as the sample size used and the agency setting are bounded. The 
use of discretion in general task at work indicated as slightly skewed towards 'frequently' by almost 20 per cent.

Surprisingly, there were 45 staff admitted to use discretion in frequent term and another 34 of them agreed in using discretion occasionally. Only one staff recorded had never use discretion when it comes to policy and procedural matters. This shows the propensity of some leeway involved among the staff while resolving problems concerning policy practice in the agency. More than half of the participants concurred that they still relying on discretion decisions even after consulting their superiors $(n=61)$ and the co-workers $(n=62)$.

As majority of these SLBs have worked quite sometime in the agency, their work experiences somehow did influence whether or not to use discretion during handling the clients' cases. A long period of time working with relatively similar nature of work has informed their practices, knowledge and networking in the job scope. Fifty-five per cent reported to use discretion as their approach to accomplish the task at hand which indeed subsequently addressed the organization's mission in delivering good quality of services to the public.

TABLE I. THE USE OF DISCRETION

\begin{tabular}{|l|l|l|}
\hline Item & Occasionally & Frequently \\
\hline $\begin{array}{l}\text { The use of discretion in general } \\
\text { work. }\end{array}$ & $33(41 \%)$ & $47(59 \%)$ \\
\hline $\begin{array}{l}\text { The use of discretion pertinent to } \\
\text { policy and procedure. }\end{array}$ & $34(43 \%)$ & $45(57 \%)$ \\
\hline $\begin{array}{l}\text { The use of discretion after } \\
\text { consulting the supervisor. }\end{array}$ & $19(24 \%)$ & $61(76 \%)$ \\
\hline $\begin{array}{l}\text { The use of discretion after } \\
\text { consulting the colleagues. }\end{array}$ & $18(22 \%)$ & $62(78 \%)$ \\
\hline $\begin{array}{l}\text { The use of discretion after } \\
\text { referring to own experiences. }\end{array}$ & $38(47 \%)$ & $42(53 \%)$ \\
\hline $\begin{array}{l}\text { The use of discretion with the aim } \\
\text { of achieving the organizational } \\
\text { goals. }\end{array}$ & $26(45 \%)$ & $44(55 \%)$ \\
\hline
\end{tabular}

\section{Discretion Decisions on Specific Matters}

The next part is looking on the participants' judgment of conditions on what matter do they think they might adapt discretion in their decision making process. Seemingly, from TABLE II the government officers in this agency did refer to the organization regulations and standard of procedures (SPO) up to more than 81 per cent prior to consider of using discretion to handle the problems $(n=61)$. Only four of them conceded they referred to these official documents by 60 per cent or less. Around 18 per cent of the staff fall on the middle category (referred to information on regulations and SOPs of the agency by 61 per cent to 81 per cent). It was reported that one officer did not answer this question for both; regulations and standard of procedures documents. 


\begin{tabular}{|l|l|ll|}
\hline $\begin{array}{l}\text { Percentage of organization regulations that } \\
\text { participants referred to }\end{array}$ \\
\hline Less than $60 \%$ & $61 \%-80 \%$ & $\begin{array}{l}\text { More } \\
81 \%\end{array}$ & than \\
\hline 4 & 14 & 61 & \\
\hline $\begin{array}{l}\text { Percentage of admitted } \\
\text { organization's standard of procedring }\end{array}$ to \\
\hline Less than 60\% & $61 \%-80 \%$ & $\begin{array}{l}\text { More } \\
81 \%\end{array}$ & than \\
\hline 4 & 14 & 61 & \\
\hline
\end{tabular}

Further information was gathered from the focus group discussion among the participants. These sessions were held to establish the emergence themes on the underlying reasoning for using discretion in their routine tasks. Qualitative data reveals the use of discretion mostly demanded among cases involving children (minor), elderly and incapacitated people such as person with disability whether physically or mentally, person with addictions of substance abuse and also cases which require immediate attention of action for instance family violence, child abuse and negligence, court order for interim protection order, et cetera.

On the similar note, the participants responded that they are normally taking into account several aspects which they consider in expediting the process on action of the problem from the angle of socio-ecomics of the clients, time and cost effect manner as well as reducing bureaucracy issues in a workplace. The officers tend to use discretion for lower income clients if it is related to seeking financial aids or lawyering matters. Long and tedious proceeding has their priority than the shorter standard of procedures.

Among type of challenges faced by these government officers largely upon time constaint in executing the task interwined with the case workloads that they need to attend. In addition, lack of resources namely short of staff, issues in logistics and facilities that may impede the services delivery to the people.

The findings is parallel with the results obtained in the research regarding the SLBs whom handling the Dutch immigration policy in Netherlands (Hoyle, 2014). The execution part as well as the policy formation seem incongruent with each other which arose problems during the implementation by local immigration officers. Thus, discretion is used in interpreting and implementing the policy. The application of discretion in different poles concludes that it influences the policy despite being in the lower layers of a hierarchy (Taylor and Kelly, 2006; Gambrill, 2011).

On the other hand, discretion allows frontline workers to intervene on behalf of their clients and may also discriminate amongst them. This unfortunately permits individuals take priority over others (Vinzant, Denhardt and Crothers, 1998). The research was conducted within the medical area where some patients may require faster or more extensive treatment than the others. Therefore, medical practitioners such as doctors and nurses are in need of discretion decision at times to continue their tasks.

\section{Conclusion}

The Lipsky's street level bureaucracy theory in 1980 has proven to be fundamental in this study. The whole analysis of discretion in this study showed workers at operation level have the possibility to exercise discretion due to their complexity of working environments. It 
seems logical in some sense, however, the degree of extent in using discretion is questioned. Like any other professionals, if not all, most employees have the desire to strightly obey and adhere to regulations and procedures of the organization. Nonetheless, their work environment as well as individual values may from time to time influence their decisions especially in regard to assisting the under privileged clients.

Being a civil servant in an important ministrial portfolio, the demand to a good service delivery for clients is equally as crucial as the demand from the organization itself. Discretion is envitable, but to a certain degree with the wisdom of professional working experiences and good intention to swift the whole process of servicing may outweigh its flaw. In summary, whether the nature of work or moral principles pinned as the external drive of motivation in using discretion, the course of action should be leaning toward positive outcomes of the scale rather than finding it balanced.

\section{Acknowledgment}

The authors wish to thank Ministry of Education (Malaysia) for funding this research project under the Fundamental Research Grant Scheme as well as to Universiti Utara Malaysia for the administrative assistances.

\section{References}

Belabas, W., \& Gerrits, L. (2017). Going the extra mile? How street-level bureaucrats deal with the intergration of immigrants. Social Policy and Administration, 51(1), 133-150.

Dworkin, G. (1977). Taking rights seriously. London: Duckworth.

Lipsky, M. (1980). Street level bureaucracy: Dilemmas of the individual in public service. New York: Russell Sage Foundation.

Loyens, K., \& Maesschalck, J. (2010). Toward a theoretical framework for ethical decision making of street-level bureaucracy: Existing model reconsidered. Administration \& Society, 42(1), 66-100.

Galligan, D. (1990). Discretionary powers. Oxford: Clarendon Press.

Gambrill, E. (2011). Evidence-based practice and the ethics of discretion. Journal of Social Work, 11(1), 26-48.

Hoyle, L. (2014). "I mean, obviously you're using your discretion": Nurses use discretion in policy implementation. Social Policy and Society, 13(2), 189-202.

Hupe, P., \& Hill, M. (2007). Street-level bureaucracy and public accountability. Public Administration, 85(2), 279-299.

Marschall, M., Shah, P., \& Ruhil, A. (2011). The study of local elections (symposium). Editor's introduction: A looking glass into a future. Political Science and Politics, 44(1), 97-100.

Meyers, M., \& Vorsanger, S. (2003). Street-level bureaucrats and the implementation of public policy. In Handbook of public administration. London: Sage.

Mutereko, S. (2009). Policy implementation and street-level bureaucrats' discretion, autonomy and coping mechanisms: A case study of national curriculum statements at a school in Pietermaritzburg. Unpublished.

Sibanda, G. (2011). Street-level bureaucracy: A case study of the implementation of the adult basic education and training policy in the Pinetown Education District of KwaZulu-Natal, Unpublished.

Scott, P. (2012). Assessing determinants of bureaucratic discretion: An experiment in streetlevel decision making. Journal of Public AdministrationResearch and Theory, 7(1), 35-58. 
Taylor, I. (2007). Discretion and control in education: The teacher as street-level bureaucrat. Educational Management Administration \& Leadership, 35(4), 555-572.

Taylor, I., \& Kelly, J. (2006). Professionals, discretion and public sector reform in the UK: Revisiting Lipsky. International Journal of Public Sector and Management, 19(7), 629-642.

Tummers, L., Steijn, A., \& Bekkers, V. (2012). Explaining willingness of public professionals to implement public policies: Content, context, and personality characteristics. Public Administration, 90(3), 716-736.

Vinzant, J., Denhardt, J., \& Crothers, L. (1998). Street-level leadership: Discretion and legitimacy in front-line public service. Washington: Georgetown University Press. 